Research.

\title{
THE ANALYSIS OF THE COMPANIES PROFITABILITY LEVEL EITHER BEFORE OR AFTER THE MERGER (Case Study Upon 7 Open Companies in 2012)
}

\author{
Lala Intan Gemala Sari \\ Lecturer at Politeknik BBC Sukabumi \\ Dwi Asih Surjandari
}

\begin{abstract}
This study aims to analyze the profitability of companies before and after merger. The study of the population is the registered companies in Indonesia Stock Exchange in 2012. Having applied technical purposive sampling, finally this study has selected 7 companies as the research samples.

The level of profitability of companies assessed using the Return On Asset (ROA), Return On Investment (ROI), Return On Equit (ROE), Earning Per Share (EPS). Observation period of this study is one year before and one year after merger. Statistic test used is normality one sample test.

The result determined that there had not been any increasing of the ROA of the companies happened after the merger. However, the ROE, ROI and EPS had been increased.
\end{abstract}

Keywords: merger, acquisition, profitability ratio.

\section{INTRODUCTION}

\section{A. Background of The Research}

One of the strategies to be a big and competitive company is by having been thru an expansion either internally or externally. Internal expansion would happened when the division of the company has been developed normally thru the activity of capital budgeting, and external expansion has referred to the business combination. Business combination according to the accountancy term has 3 types, merger, consolidation and acquisition (Putra, 2010).

Abdul Moin (2007) defined that merger and acquisition can be defined based on the perspectives of the corporate finance and the strategic management. Refers to the perspective of the corporate finance, merger and acquisition are a long term investment decision related to the capital budgeting since the business reliability should have to be analyzed accordingly. But refers to the strategic management perspective, merger and acquisition are an alternative strategy of the development thru an external path to reach the goals of the company. According to the perspectives of corporate finance and strategic management, the aims of merger and acquisition are developing more or less a long-term of the company competitiveness and at the end it can increase the value of the company itself (Sumarsih, 2005).

Profitability ratio is a ratio describing the ability of a company to gain the profit applying all the applicable resources which is marketing, cash, capital, total of the employees, branches, etc. (Syafri, 2008:304). The measurement of the company profitability has been measured according to the total sales, total of the asset and individual capital (Syamsuddin, 2011). 
The profitability ratio of this research has applied ROA (Return On Asset), ROE (Return On Equity), ROI (Return On Investment) and EPS (Earning Per Share). According to Hanafi and Halim (2003:27), ROA (Return On Asset) is the financial ratio of the company related to the profitability which is measuring the capability of a company gaining the profit refers to its revenue, asset and particular shares capital. However, according to Lukman Syamsuddin (2009, page 64) determined that ROE (Return On Equity) is a measurement regarding the reserved income for the owner of the company (either shareholders or preference shareholders) due to the capital they have invested in the company.

Comparing this research with the former one is that the former research has not diversified the type of the companies and has applied four groups of the financial ratio to measure the company performance during the research period time of 19972000. But, this research has been focusing to the manufacturing companies registered at $\mathrm{BEI}$ in order to measure the companies performances during the research period of 2005-2009. Nevertheless this research has extended the research time within 3 years to have the proximity of the profitability ratio and the research variables of Return On Equity (ROE), Return On Investment (ROI), ROA (Return On Assets) and EPS (Earning Per Share).

\section{B. Research Problem Design}

Based on the background of this research, the writer has defined the following research designs:

1. Has an increasing of the Return On Asset (ROA) of the company been occurred before and after the merger of the companies?

2. Has an increasing of the Return Of Equity (ROE) of the company been happened before and after the merger of the companies?

3. Has an increasing of the Return On Investment of the company been occurred before and after the merger of the companies?

4. Has an increasing of the Earning Per Share (EPS) of the company been happened before and after the merger of the companies?

\section{The Objectives and the Contribution of the Research.}

Based on the background and the problems design which have been described before, the objectives of this research are as follows:

1. To analyze the profitability level of the company before and after the merger of the companies by using the Return On Asset (ROA).

2. To analyze the profitability level of the company before and after the merger of the companies by using the Return Of Equity (ROE).

3. To analyze the profitability level of the company before or after the merger of the companies by using the Return On Investment (ROI).

4. To analyze the profitability level of the company before and after the merger of the companies by using the Earning Per Share (EPS).

\section{LIBRARY REVIEW, RESEARCH DESIGN, AND HYPOTHESIS}

\section{A. Fundamental Theory}

Dharmasetya and Sulaimin (in Wangi, 2010) determined that the motivation of the companies to perform the business combination is based on some related theory, as follows:

\section{Signaling Theory}

According to Jamaan (2008), Signaling Theory has defined how a company should have given a signal to the financial report users. This kind of signal is consisting of the information about what has been done by the management to meet

Lala Intan Gemala Sari and Dwi Asih Surjandari: The Analysis of The Companies Profitability Level Either Before or After The Merger (Case Study Upon 7 Open Companies in 2012) 
the owner of the company expectation. Such the signal can be a promotion or other information declaring that the related company is better than others. The signaling theory has described that a signal has been provided by the manager to minimize asymmetric information.

\section{B. Profitability Benefit}

A profitability index has been applied as a measurement criteria of the result of the operational company which is very important and can be used as the following:

1. An analysis of the effort gaining the profit indicated to detect the result of profit or loss which has been achieved by such an information object within a certain of the accountancy intervals.

2. Profitability can be usable to identify the criteria which is a very important thing to evaluate the success of the company refers to the capability and motivation of the management.

3. Profitability is a tool to figure out the projection of the company's profit since it has been describing the correlation between the profit and the total capital invested.

4. Profitability is a controlling system for the management that can be used by the internal parties to set up a target, budget, coordination, evaluation of the performance of the operational company and as a fundamental decision making.

\section{DESCRIPTION OF THE RESEARCH OBJECTS}

\section{A. The Company History}

An open company is an industry that is processing the raw materials to be marketable finished products.

This research has selected 7 (seven) companies to study, they are as follows;

1. PT. Agung Podomoro Land Tbk.

2. PT. Alam Sutra Realty Tbk.

3. PT. Cowell Development Tbk.

4. PT. Kalbe Farma Tbk.

5. PT. Mitra Bahtera Segara Sejati Tbk.

6. PT. Solusi Tunas Pratama Tbk.

7. PT. Tunas Ridean Tbk.

\section{B. The Scope of Business}

The scope of KBLF activities has covered the developing department, manufacturing and trading of the pharmaceutical products, medication products, nutrition, supplement, health food and beverages, as well as health equipments including the primary health services.

\section{RESEARCH METHODOLOGY}

\section{A. Type of the Research}

Running this research, the writer has applied the comparative causal research to examine the effect of the level of the company profitability which is before and after a merger by applying ROA (Return On Asset), ROE (Return On Equity), ROI (Return On Investment) and EPS (Earning Per Share).

\section{B. The Definition and The Operational Variables}

This research has applied dependent variable by analyzing the company performance refers to the financial of the company comparing the profitability ratio which is before and after the merger and acquisition.

Lala Intan Gemala Sari and Dwi Asih Surjandari: The Analysis of The Companies Profitability Level Either Before or After The Merger (Case Study Upon 7 Open Companies in 2012) 
Sayfri, 2008:304 defined that profitability has indicated the capability of the company to get the profit at a certain interval. The company capability can be measured according to the success of the company and the ability to use the assets productively. Therefore the profitability of the company is identifiable by comparing the profit periodically with the total assets of the company or the total amount of the capital.

\section{Data Collection Technique}

This research has applied secondary data. Secondary data is the data obtained from the documentations or data base of the various resources refer to the financial report published covering the balance sheet and Profit and Loss report. The institution who has this kind of the research data is BEI.

\section{Data Analysis Method}

1. Descriptive Statistics

2. Normality Test

3. Hypothesis Test

\section{RESULT OF THE ANALYSIS AND DESCIPTION}

Based on the result of the study upon 7 aforementioned companies which has been measured by the profitability ratio, and the results are as follows:

\section{ROA (Return On Asset)}

In relation with the result of the hypothesis test regarding the ROA, this research has identified that there is not any increasing of the ROA occurred. It might be happened since after having a merger or an acquisition at the average the company has increased the profit and the value of the assets, however the increasing of the profit is unable to get along with the increasing of the assets, so that ROA value is smaller than a year before.

\section{ROE (Return On Equity)}

The result of the hypothesis test regarding the ROE, this research has indicated an increasing ROE has happened. It could be happened that after merger or acquisition the companies, on average it has got an increasing assets value and profit, so that it has increased directly the equity of the companies.

\section{ROI (Return On Investment)}

The result of the hypothesis regarding the ROI, this research has indicated an increasing of ROI has happened, it could be happened since after the merger and the acquisition of the companies, on average it has got an increasing of the value of the total sales, so that it has eased the management of the companies to invest more.

\section{EPS (Earning Per Share)}

The result of the hypothesis regarding ROA has indicated an increasing of ROA has happened, it happened sine after the merger and the acquisition the companies on average the company has increased their profit value, however, it is not significantly in compliance with the increasing of the value of their shares.

Based on the result of the hypothesis and the statistics test, it could be concluded that the increasing of ROA of the companies has happened either before the merger or after the merger. This research is in compliance with Cabanda and Pajara-Pascual in 2007 who have determined that there has not any significant changes happened for the interval either before or after the merger. 


\section{CONCLUSION AND SUGGESTIONS}

\section{A. Conclusion}

The aims of this research is to identify whether the financial performance of the companies has been changed after the merger and the acquisition by measuring the profitability ratio refers to ROA, ROE, ROI, and EPS. The following results are as follows:

1. There is not any ROA increasing of the companies happened either before or after merger.

2. There is ROE increasing of the companies happened either before or after the merger.

3. There is ROI increasing of the companies happened either before or after the merger.

4. There is EPS increasing of the company happened either before or after the merger.

\section{B. The Research Implication}

This research has still had the limitation and the weakness:

1. This research has measured only for 1 year period of time after the merger and the acquisition happened since the financial data of the report of 2014 has not been provided yet.

2. The writer could not focus on one type of the companies which is the manufacturing companies, since in 2012 there have been only a few of the companies executed a merger or an acquisition.

\section{Suggestions}

1. It is suggested that the next researcher will study the performance of the companies performance either before or after the merger, for example 5 years period of time after the merger and the acquisition happened so that an accurate result will be obtained properly.

2. This research has not yet indicated other factors that could affect the financial performance of the companies having been done a merger or an acquisition, for example : the applicable accountancy method of the companies.

3. The future researchers are able to add more new variables related to the financial performance.

\section{REFERENCES}

Apriyada, K. (2013). Pengaruh Struktur Kepemilikan Saham, Struktur Modal dan Profitabilitas Terhadap Nilai Perusahaan. Denpasar: Jurnal IImiah Universitas Udayana.

Belkaoui, Ahmed R. 2007. Accounting Theory. Buku 2. Jakarta: Salemba Empat.

Bon, Kim Jeong, Krinsky, Itzhak, dan Lee, Jason. 1993. Motives for Going Public and Underpricing: New Findings from Korea. Journal of Business Financial and Accounting. January. p. 195-211.

Brigham, E. F \& Houston, (2011). Dasar-dasar Manajemen Keuangan, Edisi Sebelas, Alih Bahasa Ali Akbar Yulianto, Penerbit Salemba Empat, Jilid 2, Jakarta.

Carlson, S. J. Dan Bathala, C. T. 1997. Ownership Differences and Firm"s Income, Smoothings Behaviour. Journal of Business Finance \& Accounting, 24 (2), 179196.

Chen, R. Carl, dan Steiner, T. L. 1999. Managerial Ownershipand Agency Conflict: A

Lala Intan Gemala Sari and Dwi Asih Surjandari: The Analysis of The Companies Profitability Level Either Before or After The Merger (Case Study Upon 7 Open Companies in 2012) 
Nonlinear Simultaneous Equation Analysis of Managerial Ownership, Risk Taking, Debt Policy and Dividend Policy, Financial Review, Vol. 34, pp. 119-137.

Christiawan, Yulius, J., \& Tarigan, J. (2007). Kepemilikan Manajerial: Kebijakan Hutang, Kinerja dan Nilai Perusahaan, Jurnal Akuntansi dan Keuangan Vol 9. No.1, 22-23

Diyah, Pujiati, dan Widanar, Erman. 2009. "Pengaruh Struktur Kepemilikan Terhadap Nilai Perusahaan: Keputusan Keuangan sebagai Variabel Intervening. "Jurnal Ekonomi Bisnis dan Akuntansi Ventura, Vol. 12. No.1, h. 71-86.

Fama, E. F. 1978." The Effectofa Firm"s Investment and Financing Decision on the Welfareofits Security Holders. "American Economic Review 68: June 272-284.

Gallagher, Timothy J. and Joseph D. 2007. Financial Management. Prentice Hall, inc, United State of America.

Ghozali, Imam. 2011. Aplikasi Analisis Multivariate dengan Program SPSS. Semarang: Badan Penerbit Universitas Diponegoro.

Graham, John, Scott Smart, and William Megginson (2010), Corporate Finance (3rd Edition), Cengage South-Western

Horne, James C. V., dan Wachowicz, John M. 2005. Fundamental of Financial Management. Buku satu edisi kedua belas. Jakarta: Salemba Empat.

Ismiyanti, F \& Mamduh, M. H. (2004). Struktur Kepemilikan, Risiko, dan Kebijakan Keuangan: Analisis Persamaan Simultan. Jurnal Ekonomi dan Bisnis Indonesia, Vol 19, No 2, 176-196.

Jama"an. 2008. Pengaruh Mekanisme Corporate Governance, dan Kualitas Kantor Akuntan Publik Terhadap Integritas Informasi Laporan Keuangan (Studi Kasus Perusahaan publik yang Listing di BEJ). Semarang: Universitas Diponegoro

Jensen, M.C. dan Meckling, W.H. 1976. Theory of the Firm : Managerial Behavior, Agency Costsand Ownership Structure. Journal of Financial Economics, Oktober, 1976, V.3, No.4, pp. 305-360. Avalaible from: audit Delay, Vol.10, No.3, h.109-121.

Keown, Arthur, J, et al, (2011). Dasar-Dasar Manajemen Keuangan. Diterjemahkan oleh Chaerul D Djakman. Edisi Ketujuh. Buku 1. Jakarta: Salemba Empat.

Kusumajaya, D. K. O. 2011. Pengaruh struktur modal dan pertumbuhan perusahaan terhadap profitabilitas dan nilai perusahaan pada perusahaan manufaktur di bursa efek Indonesia. Universitas Udayana, Denpasar: Tesis yang tidak dipublikasikan.

Lee, C. Rosentein, SN, Rangan, dan Davidson III, W. N. 1992. "Board Composition and Shareholder Wealth: The Case of Management Buyout". Financial Management, 21 : 58-72.

Modigliani, F dan Miller, M. 1963. Corporate Income Taxses and The Cost of Capital: A Correction, American Economic Review, 53, June, pg. 433-443.

Morck, R., Shleifer, A., \& Vishny, R.W. (1988). Management Ownership and Market Valuation: An Empirical Analysis. Journal of Financial Economics, Vol. 20, hal. 293315.

Mulyadi. 2007. Activity Based Cost System. Ed. 6. Yogyakarta: UPP STIM YKPN.

Permanasari, W. I. (2010). Pengaruh Kepemilikan Manajemen, Kepemilikan Institusional dan Corporate Social Responsibility Terhadap Nilai Perusahaan Jurnal Ekonomi dan Bisnis. Universitas Diponegoro 22, 21-28.

Riswari, Dyah Ardana. 2012. "Pengaruh Corporate Social Responsibility Terhadap Nilai Perusahaan dengan Corporate Governance sebagai Variabel Moderating. Tesis tidak dipublikasikan. Universitas Diponegoro. 
Rodoni, Ahmad dan Herni Ali, (2010). Manajemen Keuangan. Edisi Pertama. Jakarta: Mitra Wacana Media.

Ross, S. 1977. The Determination of Financial Structure: the Icentive Signalling Approach, Bell Jounal Of Economics, 8, 23-40

Salvatore, Dominick. 2005. Ekonomi Manajerial dalam Perekonomian Global. Salemba Empat: Jakarta.

Satmoko, A \& Sudarman. (2011). Impact of Personal Taxes on Corporate Dividend Policy and Capital Structure Decisions, Finance Management. Financial Management Association. 19 (2), pp. 21-31

Sawir, Agnes, 2009. Analisa Kinerja Keuangan dan Perencanaan keauangan Perusahaan, PT. Gramedia Pustaka Utama, Jakarta.

Shiller, R. J. Dan Pound, J. 1989. Survey evidence on the divusion of interest and information among investors. Journal of Economic Behavior and Organization12 (1), 47-66.

Siallagan, Hamonangan dan Machfoedz, M. 2006. Mekanisme Corporate Governance, Kualitas Laba dan Nilai Perusahaan. Disampaikan pada Simposium Nasional Akuntansi (SNA )IX Padang.

Sitepu, Citra Noveli. 2010. Pengaruh Kinerja Keuangan Terhadap Harga saham pada Perusahaan Industri Makanan dan Minuman yang terdaftar di BEI, Jurnal Akuntansi, Universtias Sumatera Utara fakultas Ekonomi Medan.

Slovin, Myron B. dan Sushka, Merie E. 1993. Ownership Concentration, Corporate Control Activity, and Firm Value: Evidence from The Death of Inside Blockholder, Journal of Finance; Vol. XLVII, No. 4. 30-50

Smith, Michael P. 1996. "Shareholder activision by institusional investor, evidencefro, calpers", Journal of Finance, Vol. XLI, No. 1. 45-70

Subramanyam, K. R. 1996. "The Pricing of Discretionary Accruals". Journal of Accounting and Economics, pp. 249-281. Retrieved: March2 ${ }^{\text {nd }}, 2007$, from ProQuest database.

Sujono dan Soebiantoro, Ugy. 2007. Pengaruh Struktur Kepemilikan Saham, Leverage, Faktor Intern dan Faktor Ekstern Terhadap Nilai Perusahaan (Studi empiric pada perusahaan manufaktur dan non manufaktur di Bursa Efek Jakarta). Dalam Jurnal Manajemen dan Kewirausahaan, 9(1) : h: 43-47.

Suwardjono. 2005. Teori Akuntansi: Perekayasaan Pelaporan Keuangan (Edisi III). Yogyakarta: BPFE.

Syafri Harahap, Sofyan, 2008. Analisa Kritis atas Laporan Keuangan, PT. Raja Grafindo Persada, Jakarta.

Wahyudi, Untung dan Pawestri, H. P. 2006. Implikasi Struktur Kepemilikan Terhadap Nilai Perusahaan: Dengan Keputusan Keuangan Sebagai Variabel Intervening. Disampaikan pada Simposium Nasional Akuntansi (SNA) IX Padang.

Wening, Kartikawati. 2009. "Pengaruh Kepemilikan Institusional Terhadap Kinerja Keuangan

Wolk, Harry, Michael G. Tearney, dan James L Dodd. 2000. Accounting Theory: A Conceptual and Institutional Approach. South-Western College Publishing

Financeroll.co.id

http://societykamaru.blogspot.com

http://www.realminers.com

www.idx.co.id

www.sahamok.com

Lala Intan Gemala Sari and Dwi Asih Surjandari: The Analysis of The Companies Profitability Level Either Before or After The Merger (Case Study Upon 7 Open Companies in 2012) 
The Accounting Journal of BINANIAGA Vol. 02, No. 02, December 2017

PISSN: $2527-4309$

EISSN: $2580-1481$

This page intentionally be emptied.

Lala Intan Gemala Sari and Dwi Asih Surjandari: The Analysis of The Companies Profitability Level Either Before or After The Merger (Case Study Upon 7 Open Companies in 2012)

Page : 84 